\title{
Female Breadwinner Families: Their Existence, Persistence and Sources*
}

\author{
Robert Drago ${ }^{\dagger}$, David Black ${ }^{\ddagger}$ and Mark Wooden ${ }^{\ddagger}$ \\ ${ }^{\dagger}$ Department of Labor Studies and Industrial Relations, \\ The Pennsylvania State University \\ Melbourne Institute of Applied Economic and Social Research, \\ The University of Melbourne
}

\section{Melbourne Institute Working Paper No. 19/04}

ISSN 1328-4991 (Print)

ISSN 1447-5863 (Online)

ISBN 0734031610

\begin{abstract}
August 2004
* This paper reports on research being conducted as part of the research program, "The Dynamics of Economic and Social Change: An Analysis of the Household, Income and Labour Dynamics in Australia Survey". It is supported by an Australian Research Council Discovery Grant (DP0342970). The paper uses the data in the confidentialised unit record file from the Department of Family and Community Services' (FaCS) Household, Income and Labour Dynamics in Australia Survey, which is managed by the Melbourne Institute of Applied Economic and Social Research. The findings and views reported in the paper, however, are those of the authors and should not be attributed to either FaCS or the Melbourne Institute. Financial support for Robert Drago's travel and accommodation was also provided by the Faculty of Economics and Commerce at the University of Melbourne.
\end{abstract}

Melbourne Institute of Applied Economic and Social Research

The University of Melbourne

Victoria 3010 Australia

Telephone (03) 83442100

Fax (03) 83442111

Email melb-inst@unimelb.edu.au

WWW Address http://www.melbourneinstitute.com 


\begin{abstract}
We develop a typology for understanding couple households where the female is the major earner - what we term female breadwinner households - and test it using data from the first two waves of the HILDA Survey. We distinguish temporary from persistent female breadwinner households and hypothesise, and confirm, that these two groups diverge on demographic, socio-economic status (SES), labour market and family commitment characteristics. Among the persistent group we further distinguish those couples where the dominance of a female earner is related to economic factors and those where it appears associated with a purposeful gender equity strategy. We again hypothesise and confirm that these household types significantly diverge, finding that men in the economic group exhibit low SES, poor labour market position, and low levels of commitment to family, while both the women and men in the equity type often achieve positive outcomes regarding gender equity and economic and family success.
\end{abstract}

\title{
Keywords:
}

dual-earner couples, female breadwinners, family structure, gender-role ideology, HILDA Survey, longitudinal data 


\section{Female breadwinner families:}

\section{Their existence, persistence and sources}

It is widely recognised that profound changes in family structure and employment patterns have taken place in recent decades. Prominent here have been the rise in lone-parent and single-person households and the relative decline in the numerical dominance of the traditional nuclear family unit (Martin and Kats 2003). Major changes have also occurred within married couple households, with couples today far less likely to rely solely on the male as the source of earned income. Data from the U.S. Current Population Survey, for example, indicate that dual earner couples in 2001 represented 59 per cent of all marriedcouple families, up from 44 per cent in 1967, with a further five per cent of couples dependent entirely on the earnings of the female (Bureau of Labor Statistics 2004, Table 19: 54). Of course, in many dual-earner couple families the female will still assume a secondary role, reflected in the relatively high incidence part-time work among married women. Nevertheless, data confirm that this is also slowly changing, with 24 per cent of wives in dual-earner couples earning more than their husbands (Bureau of Labor Statistics 2004, Table 21: 56).

These are trends that are almost certainly shared by other countries. In Australia official Labour Force Survey data indicate that 50 per cent of all employed civilians were married to an employed spouse in June 2001. ${ }^{1}$ This compares with a figure of 49 per cent in the U.S. Dual-earner couples in Australia, however, account for a smaller share of all couple households than in the U.S. (50\% compared with 59\%), but as in the U.S., the trend is distinctly upwards. Data from the 1982 Families Survey, for example, indicates that in 44 per cent of married couple income units the female partner was employed (ABS 1984). Labour Force Survey data suggest that the comparable figure for 2001 was 55 per cent.

The significance of these trends is reflected in a small but growing body of research concerned with the impact of role reversal within families on marital discord and divorce (e.g., Heckert et al. 1998; Oppenheimer 1997; Rogers and DeBoer 2001), marital role quality (Brennan et al. 2001), the self-esteem of men (Hood 1986), and the household division of labor (Baxter et al. forthcoming). These studies, however, typically treat female breadwinning (that is, families where the female is the major earner) as an independent 
variable, and do not ask why such families exist in the first place. This is the major aim of the present study.

We begin by first developing a typology that identifies three distinct types of female breadwinner families. We then use recent nationally representative survey data from Australia to estimate the number of each of these types of families in the population. A key feature of the data used is that they are longitudinal, thus enabling us to distinguish temporary from persistent female breadwinner families. Among the persistent group, we further distinguish those couples where the dominance of a female earner appears to be related to economic factors and those where it appears to be associated with a purposeful gender equity strategy. Finally, we ask whether the different family categories identified by this typology are sensible in terms of exhibiting systematic relationships with other family and individual characteristics.

The importance of our typology lies in the possibility of correcting popular understandings regarding female breadwinner families. For example, the media in the U.S. often uses the figure that couples where the female earns more than the male comprise around one-quarter of dual-earner couples as evidence of improved levels of gender equity in the labor market. But if the within-couple earnings differential is only temporary rather than persistent, these cross-sectional estimates will tend to overstate both the extent of female breadwinning over time and the extent of gender equity in the labour market as a result. Further, among these families, the media tend to focus on "Mr Mom" families with the type of stay-at-home father found in the movie of the same name, performing traditionally female tasks such as child rearing, cleaning, and cooking (Halliday 2004). According to earlier research, the image of a man with traditional gender ideology losing his job, and throwing himself somewhat haplessly but wholeheartedly into cleaning, cooking and changing diapers in response, tends to overstate the contributions of such men, who typically reduce their contributions to housework following job loss (Gerson 1993). This image also does a disservice to men who believe in gender equity and view competence in household tasks as a signal of their commitment to their families and their beliefs (Williams 1999). Further, although the existence and publicising of Mr Mom families might help to break down gender stereotypes, it also affirms the traditional breadwinner / homemaker division of labor that feminists fought so long to change, and that is associated with depression, anxiety and psychological distress for women who are homemakers (Rogers and DeBoer 2001). 


\section{Typology and Predictions}

Our typology involves three types of female breadwinner families. First are temporary female breadwinner families wherein the woman earns more than the man at one point in time but not at others. Temporary female breadwinner families may emerge accidentally in cases where the woman experiences unusually high earnings or if the man is briefly unemployed or for other reasons temporarily receives low earnings. Alternatively, they might also represent a purposeful response to economic uncertainty. For example, one member of the family may take a job with relatively stable earnings to insure the family against earnings fluctuations affecting the other member, as might occur when one member of the couple is employed in consulting, receives sales commissions, owns a small business, or works as a professional accountant, lawyer or doctor in private practice. Regardless of whether temporary female breadwinner families represent a conscious strategy or are accidental, the key point regarding their existence is that although the family may be dependent on the woman's earnings, the woman is not necessarily the more economically powerful member of the couple.

Second, among persistent female breadwinner families, we believe there are two types. In one case, short-handed by the term economic, the family may fall into female breadwinner status because of adverse events affecting the man, such as long-term unemployment or persistently low earnings. Note that such families need not reflect labour market success by the woman; the woman's earnings might be low, but the man's even lower. The family may, quite differently, take on the status as a conscious strategy to maximise income, as might be true when the woman holds higher educational credentials or greater professional experience (and note that women currently comprise a majority - 56 per cent - of employed persons holding bachelors' degrees in the Australian labour market ${ }^{2}$ ). In cases where the family form represents an income maximisation strategy or where the man has fallen on hard economic times, the family is both highly dependent on the woman's income and she holds the upper hand with regard to economic power in the family. ${ }^{3}$

Other persistent female breadwinner families may be driven by an ideology of gender equity. The distinction between economic and equity types is consistent with the claim by Brennan et al. (2001) that gender role ideology (GRI) is an important moderator for understanding the effects of female breadwinning on marital quality. Given they take GRI as exogenous, it seems reasonable to extend their argument to incorporate the possibility that GRI is a determinant of both whether and why female breadwinning emerges in a family. Specifically, where the man holds strong beliefs in gender equity, he might be willing to 
subsume his career aspirations, geographically relocate for the woman's career advancement, and/or take on a greater burden of housework and child care in order to create a more egalitarian family structure. In such cases the intra-family earnings differential is largely irrelevant; in some equity-focused families the man will earn most while in others the female will. In the latter instance the family will be classified as a female breadwinner family, but irrespective of how dependent the family is on the woman's earnings, power within the home will be shared relatively equally. These families may, therefore, have much in common with the 50-50 families analysed by Risman (1998) and Deutsch (1999), where the term 50-50 is used to denote relatively equal sharing of household responsibilities, employment commitments and power. If this interpretation is correct, these families should not be viewed as simply male breadwinner families with gender roles reversed.

Although the data used in this analysis do not provide direct evidence regarding why families enter a particular status, we can ask whether the typology, once operationalised, helps to explain divergence across female breadwinner families. At the simplest level, we can test the following two hypotheses:

Hypothesis 1. Temporary and persistent female breadwinner families will significantly diverge on various family and individual characteristics.

Hypothesis 2. Economic and equity types of persistent female breadwinner families will significantly diverge on various family and individual characteristics.

We later test hypotheses 1 and 2 using variables for demographic characteristics, socioeconomic status (SES), labour market position, family commitments, and gender role identity (GRI). To the extent the hypotheses are confirmed, we will have evidence that our typology is important in a statistical sense.

However, specific patterns of difference are more crucial to the fundamental question of whether the typology helps to make sense of female breadwinning. Four specific or subhypotheses move us in this direction.

Hypothesis 1a. According to various couple- and individual-level measures, temporary female breadwinner families should exhibit characteristics intermediate or between those exhibited by male breadwinner as opposed to persistent female breadwinner families.

Hypothesis 1a is based on the statistical argument that, whatever forces drive families to move into the persistent female breadwinner category, those forces will be less pronounced 
among temporary female breadwinner families. For example, if women tend to be more highly educated in persistent female, as opposed to persistent male, breadwinner families, then women in temporary breadwinner families may exhibit an intermediate level of education. This hypothesis, if confirmed, suggests that temporary female breadwinner families do not accurately reflect or at least do not epitomise female breadwinner families. Stated differently, temporary female breadwinner families may introduce statistical noise into any study of female as opposed to male breadwinner families.

However, temporary female breadwinner families may also have an economic basis wherein the more stable income of one partner is used as insurance against earnings fluctuations for the other. Since either partner might in this case be the one with more stable earnings, we can predict that:

Hypothesis $1 b$. Relative to persistent female breadwinner families, men and women in temporary female breadwinner families will exhibit higher rates of unemployment.

We interpret the equity type of persistent female breadwinner family as akin to 50-50 families. Previous research in the U.S. suggests that such families tend to be white, exhibit high levels of SES, and have strong positions in the labour market, but with relatively low levels of working time, consistent with a high level of commitment to the family (Deutsch 1999; Risman 1998). The high levels of family commitment should be reflected in the husbands taking on a heavy burden of household responsibilities and child care to the extent the equity terminology accurately reflects these families. More generally, to the extent our equity categorisation is appropriate, it should not so much reflect a strategy to maximise the woman's time devoted to paid work, but rather a device for enhancing family functioning while simultaneously achieving economic success.

As noted earlier, economic persistent female breadwinner families emerge through a variety of circumstances. Some may represent a strategy to maximise family income by emphasising the woman's career. Others may arise where the man experiences adversity in the labour market or when both members of the couple are low earners. In all of these cases, it is reasonable to suggest:

Hypothesis 2a. Relative to men in the equity type, the men in economic persistent female breadwinner families will exhibit lower SES, a weaker position in the labour market, and a lesser commitment to family. 
Although the women in these economic female breadwinner families may often wield relatively greater power in the family, the commitment of the man to the family is likely to be weaker than in the equity type of persistent female breadwinner family. As a result, we expect:

Hypothesis $2 b$. Relative to women in the economic type, the women in equity persistent female breadwinner families will exhibit higher SES, and rear a larger number of children while simultaneously performing less housework and child care.

To the extent these hypotheses are confirmed, they would lend support to two opposing views of female breadwinning. Family sociologists using a functionalist framework argue that male breadwinner families with women specialising in unpaid childrearing and housework are superior to other forms in terms of providing stability, continuity, and marital happiness (Becker 1981; Parsons 1949), an argument recently extended to include families where the woman is part-time employed and the man remains the primary earner (Hakim 2001). The existence of economic persistent female breadwinner families to the extent they indeed involve low levels of commitment by the man to family, and to the extent they rear fewer children, supports the functionalist view. However, the existence of equity persistent female breadwinner families, and their ability to fulfill economic and family objectives, supports the feminist view that equality is both normatively valuable and attainable (e.g., Barnett and Rivers 2004; Deutsch 1999; Risman 1998).

Note finally that, because we use two years of data to distinguish temporary from persistent female breadwinner families, we necessarily expand the combined proportion of female breadwinner families compared to figures generated by a cross-section at a single point in time. This result occurs because some male breadwinner families will become female breadwinner families by the second period, expanding the temporary component. By extension, if we had three years of data, the proportion of persistent female breadwinner families would decline, but the proportion in the temporary category would rise further because of families that only exhibit female breadwinning in the third year. This exercise in arithmetic highlights the importance of temporary female breadwinning, a phenomenon that will be understated even by our two-year sample, and suggests that much female breadwinning is primarily about the economic dependence of families on both the woman and the man's income. 


\section{Data and Methods}

The data used in this analysis come from the first two waves of the Household, Income and Labour Dynamics in Australia (or HILDA) Survey. ${ }^{4}$ Described in more detail in Watson and Wooden (2002), the HILDA Survey is a longitudinal household panel survey. Funded by the Australian Government, it began in 2001 with a large national probability sample of households, and involved personal interviews with all household members aged 15 years and over. In wave one (W1), interviews were obtained at 7682 households, which represented 66 per cent of all households identified as in-scope. This, in turn, generated a sample of 15,127 persons eligible for interview, 13,969 of whom were successfully interviewed. In 2002 all responding households from W1 were re-contacted. Interviews were again sought with all household members aged 15 years or over, including persons who did not respond in W1, as well as any new household members. In total, interviews for waves 2 (W2) were completed with 13,041 persons from 7245 households. Of this group, almost 12,000 were respondents from W1, which represented almost 87 per cent of the W1 individual sample. A third wave was conducted in 2003. At the time of writing, however, data were only publicly available from the first two waves.

While the coverage of the HILDA Survey is extremely broad, it is intended to have a focus on household structure and formation, income and economic well-being, and employment and labour force participation. For this analysis the most important feature of the survey is its collection of data on the both usual and financial year earnings from all adults in the household.

In studies of female earnings and marital quality, it is usual to employ both absolute and relative measures of female earnings (e.g., Rogers and DeBoers 2001). To understand female breadwinning, however, relative earnings is the relevant indicator. We therefore use data on usual gross (i.e., pre-tax) earnings at the time of survey administration at W1 and W2, with the data collected separately from each member of the couple. We initially divided the couples into three types: male breadwinner, female breadwinner, and couples where earnings were about equal. The latter category was defined to include couples where the man and woman earned within 10 per cent of each other. The 10 per cent cut-off results in a conservative estimate of the number of female breadwinner families. All figures and tests reported below. However, were replicated using a five per cent cut-off to ascertain whether the results were robust. 
Groups excluded from the analysis include lone individuals, lone parents, and nonheterosexual couples. These exclusions allow us to hone in on heterosexual couples as the relevant group for understanding female breadwinning. Because of our focus on labour market behavior, we also excluded couples where either member is below 15 years of age or above 65 years of age. Couples who were jobless at either survey wave were also excluded because they would otherwise artificially inflate the group of couples exhibiting about equal earnings, and we do not believe that joint joblessness should be viewed as a source of economic equality. These exclusions cause our sample size to fall from just under 12,000 to 3910. Further exclusions due to missing data on the characteristics of individuals and families result in a final sample of 3204 individuals.

Employing the longitudinal nature of the HILDA data, we split out temporary from persistent female breadwinner families. Given the three static family categories, there are nine possible family forms over the two year period. In light of the hypotheses provided earlier, we focus on three dynamic families forms: persistent male breadwinner, persistent female breadwinner, and temporary female breadwinner families. ${ }^{5}$ The three categories thereby excluded from the analysis are, as an empirical matter, relatively small (i.e., less than four per cent of the sample). ${ }^{6}$

Using survey results from a five-item gender role ideology (GRI) scale developed by Baxter et al. (forthcoming), we split out equity from economic types among the persistent female breadwinner families. For inclusion in the equity type, the man must answer positively (i.e., above the neutral response) on each of the five items comprising the GRI scale. All other persistent female breadwinner families are classified as economic in nature.

This procedure facilitates the estimation of the size of the three types of female breadwinner families. As a check on these figures, we also repeated the analysis using financial year earnings for 2000-2001 and for 2001-2002. Usual earnings data pertain to the period around survey administration. Because the financial year data covers a relatively long period of time - two full years rather than two points-in-time - it might provide a more accurate estimate of persistent female breadwinning. However, because the financial year data smoothes and hides earnings fluctuations within any given year, it will also tend to overstate the prevalence of female breadwinner families. We therefore provide the financial year estimates for completeness rather than as superior or inferior indicators of female breadwinning. 
With the categories defined, we turn to hypothesis testing. Hypothesis 1 concerns the possibility that temporary and persistent female breadwinner families are distinct, while Hypothesis 2 makes a similar claim regarding equity and economic types of persistent female breadwinner families. To test for these differences, we use the variables summarised in Table 1 and the sample of 3204 individuals for which complete responses to all items are available (excepting that the parent sub-sample is used for a few variables). The first set of variables are demographic, and capture the age of respondents, whether they learned English as a second language, whether they are Aboriginal or Torres Straight Islander in origin, and the average number of years spent with the current spouse or partner. The English-as-a-secondlanguage variable might be important to the extent it captures language as a barrier to inclusion and success in the labour market, while both that variable and the one for Aboriginal or Torres Straight Islander may pick up the effects of either discrimination or of cultural divergence. Note, however, that the proportion of Aboriginals and Torres Straight Islanders is small, so significant differences might not be found in the data even if they in fact exist.

The second set of variables, of relevance to most hypotheses here, captures SES. Net worth of the family should positively reflect higher family SES, while at the individual level (by gender) higher SES should appear in the greater levels of educational attainment proxied by the variable for a Bachelor's degree or higher, and similarly for the employment in a professional or managerial occupation variable. Discussed in more detail by Headey et al. (2004), net worth was constructed by summing responses to a large number of questions about the dollar value of household and individual assets and debts, and then subtracting total household debts from total household liabilities. The intention was that these questions would cover all assets and debts with the exception of home contents and accounts payable. Note that these questions were only included in W2.

The third set of variables address labour market status. Unemployment should reflect a weak position in the labour market, or perhaps work in an occupation or industry with high employment variability. Full-time employment should reflect both a strong labour market position as well as a strong commitment to paid work, while part-time employment reflects a lesser commitment to paid work and perhaps a weaker labour market position relative to fulltime employees. Work hours are taken as a reflection of commitment to paid work. 
Table 1: Variable types, descriptions and summary statistics

\begin{tabular}{llcc}
\hline \multirow{2}{*}{ Variable type } & \multicolumn{1}{c}{ Variable description } & Mean & Std. dev. \\
\hline \multirow{2}{*}{ Demographic } & Age (years) & 40.640 & 9.995 \\
& English as a second language & 0.104 & 0.305 \\
& Aboriginal or Torres Straight Islander & 0.013 & 0.114 \\
& Years married (incl. de facto marriages) & 13.864 & 10.496 \\
Socio- & Net household worth (\$000) & 456.0 & 489.0 \\
economic & Bachelor degree or higher & 0.254 & 0.436 \\
status & Professional/managerial occupation & 0.288 & 0.453 \\
Labour market & Unemployed & 0.019 & 0.138 \\
status & Full-time employed & 0.612 & 0.487 \\
& Part-time employed & 0.211 & 0.408 \\
Family & Usual weekly work hours & 32.21 & 20.10 \\
commitments & Parent of dependent child under 15 years & 0.806 & 0.396 \\
& No. of children under 15 (parent sub-sample) & 1.235 & 1.173 \\
& No. of children under 5 (parent sub-sample) & 0.417 & 0.678 \\
& Usual weekly hours spent with children & & \multirow{2}{*}{ (parent sub-sample) } \\
Sami & Preferred usual weekly work hours & 14.26 & 19.46 \\
Sample size & Usual weekly hours of housework & 12.42 & 18.33 \\
& Gender role ideology index & 26.223 & 13.08 \\
\hline
\end{tabular}

Notes: Net worth measured at W2. All other variables measured at W1. Means and standard deviations are unweighted.

Source: HILDA Survey confidentialised unit-record file, Wave 1-Wave 2, release 2.0.

The fourth set of variables concern family commitments. In general, being parents, having a larger number of children under the age of 15 years or under the age of five years, and longer weekly hours spent with children among parents, are taken as indicators of a greater commitment to family. Average preferred usual weekly work hours, very differently, are taken as an inverse indicator of commitment to family, since time spent at work cannot be devoted to family. Average weekly hours of housework is, like the earlier variables, viewed as a symptom of commitment to family. Note that there is an important exception to these interpretations. Where the man performs significantly more housework and child care, and the woman scales back time devoted to these activities, we do not interpret her behavior as reflecting a reduced level of commitment to the family.

Finally, the GRI index is summed from seven-point responses to five items concerning gender roles. The five items were as follows: 'If both partners in a couple work, they should 
share equally in the housework and care of children'; 'Mothers who don't really need the money shouldn't work'; 'Children do just as well if the mother earns the money and the father cares for the home and children'; 'It is much better for everyone involved if the man earns the money and the woman takes care of the home and children'; and 'A father should be as heavily involved in the care of his children as the mother'. The alpha for the index is .73 , suggesting it is reliable.

To test hypothesis 1 , we divide the sample into temporary and persistent breadwinner families and test for significant differences in the means of the variables described in Table 1. For proportional variables, a chi-square test of independence of classification is applied, while for continuous variables, a t-test is employed. Testing of hypothesis 2 follows a similar approach after dividing the sub-sample of persistent female breadwinner families into those that are of the economic and equity types.

To test hypothesis 1a, we require statistical confirmation of hypothesis 1 , and that the mean values of the variables for temporary female breadwinner families lie between those for persistent male and persistent female breadwinner families. ${ }^{7}$ Hypothesis $1 \mathrm{~b}$ is tested by ascertaining whether unemployment rates for men and (separately) for women in the temporary group are significantly higher than for the persistent female breadwinner families.

Hypothesis 2a requires statistical confirmation of hypothesis 2 (for men), and that the men in the economic as opposed to the equity type of persistent female breadwinner group exhibit lower means on the SES variables, higher unemployment, less full-time employment, and lower values on the family commitment variables. Hypothesis $2 \mathrm{~b}$ similarly requires statistical confirmation of hypothesis 2 (for women), and that in the equity as opposed to the economic type of persistent female breadwinner families, women exhibit higher levels of SES, are more often parents, and spent less time on housework and child care.

\section{Results}

The distribution of couples according to breadwinner status over the two year period is provided in Table 2, where the percentage figures are weighted to provide estimates of the population figures. Adding percentages across the bottom row, a total of 20.5 per cent of the couples exhibited female breadwinning in the first year (W1). Adding down the final column on the right shows that 20.1 per cent of the couples were female breadwinners in W2. 
Table 2: Percentage (numeric) distribution of couple families over time, using usual earnings and $10 \%$ cut-off

\begin{tabular}{lccc}
\hline & $\begin{array}{c}\text { Male } \\
\text { breadwinner W2 }\end{array}$ & $\begin{array}{c}\text { About equal } \\
\text { W2 }\end{array}$ & $\begin{array}{c}\text { Female } \\
\text { breadwinner W2 }\end{array}$ \\
\cline { 2 - 4 } Male breadwinner W1 & $62.1 \%$ & $3.5 \%$ & $4.1 \%$ \\
About equal W1 & $(2030)$ & $(108)$ & $(134)$ \\
Female breadwinner W1 & $3.9 \%$ & $3.7 \%$ & $2.1 \%$ \\
& $(112)$ & $(112)$ & $(60)$ \\
& $4.5 \%$ & $2.1 \%$ & $13.9 \%$ \\
\hline
\end{tabular}

Notes: Figures based upon a balanced panel of observations from HILDA W1 and W2. Numeric figures in parentheses are directly from the sample (unweighted) while sample proportions are estimated using longitudinal population weights.

To isolate the three major categories for the analysis, note that 62.1 per cent of couples exhibited male breadwinning in both waves of survey administration. These couples comprise the persistent male breadwinner group. Similarly, 13.9 per cent of the couples were persistent female breadwinners, with higher female earnings in both years. Temporary female breadwinner families are found by adding the four figures for which families exhibited female breadwinning in one period but not the other, yielding a total of 12.8 per cent. The combination of persistent and temporary female breadwinner families therefore represents an estimated 26.7 per cent of all relevant families in the population, a figure well above that for female breadwinning in any one year. Recall that, given the arithmetic involved, this combined figure would necessarily rise even further if a third wave of data were used. The groups excluded from further analysis, where the couples exhibited male breadwinning in one period but about equal earnings in the other, or where earnings were about equal in both periods, comprise a total of 11.1 per cent of the sample. They are ignored henceforth to focus on issues surrounding female breadwinning.

Switching to a five per cent cut-off to generate the categories has minimal effects (see Appendix Table 1). Persistent male breadwinning and temporary female breadwinning estimates each rise by less than two per cent, while the figure for persistent female breadwinning rises by less than one per cent. Using the 10 per cent cut-off with financial year earnings data also does not alter the estimates substantially, raising the percentage of persistent male breadwinner families from 62.1 to 63.4, the percentage of temporary female breadwinner families from 12.8 to 13.2, and the percentage of persistent female breadwinner 
families from 13.9 to 14.2. These slight increases mirror a decline from 11.1 to 9.3 in the percentage of families that exhibited male breadwinning in one period but about equal earnings in the other or about equal earnings in both periods (see Appendix Table 2).

Using male responses to the GRI index, we can distinguish economic from equity types among the 13.9 per cent of families exhibiting persistent female breadwinning. After applying the rule that men in equity types of couples will respond positively to all five GRI index items, it is estimated that 11.0 per cent of couples are persistent female breadwinner families for economic reasons, and 2.9 per cent are persistent female breadwinner families because of equity considerations.

Table 3 reports the characteristics of individuals (by gender) and of families in the three main categories for the analysis. The p-values reported in the last two columns of Table 3 allow testing of Hypothesis 1, and result from statistical tests for divergence between temporary and persistent female families either as a unit, or separately for the characteristics of the men or women involved. For the first four demographic variables, a total of seven tests were performed, and a majority of the tests yielded significance at the five per cent level or better. Relative to those in the temporary category, persistent female breadwinner families tended to be older, have been married or partnered longer, and the woman was less likely to be of Aboriginal or Torres Straight Islander origin. Of five tests for SES differences, a majority are also significant at the five per cent level, with the persistent group exhibiting higher net worth and the women more often (men less often) employed in managerial and professional occupations. Out of the eight possible tests for labour market differences, only two were significant at the five per cent level - men in the persistent group were less likely to be fulltime employed and worked shorter usual weekly hours. For the six family commitment variables, a total of nine tests were performed, and six of these were significant. The persistent female breadwinner families were more likely to be parents, but reared fewer children among the sub-samples of parents. The mothers in that group spent significantly less time with children, while the men preferred a shorter workweek and devoted a greater amount of time to housework, relative to their counterparts in temporary female breadwinner families. No significant divergence in the GRI index was found.

Out of 31 tests performed, a total of 15 yielded significance at the 5 per cent level or beyond. The odds are extremely small of finding significance in at least half of all tests if no differences in fact exist. ${ }^{8}$ We therefore take these results as supportive of Hypothesis 1. 
Table 3: Characteristics of men, women, and of families across persistent male, temporary female, and persistent female breadwinner families (p-values for hypothesis 1 in parentheses)

\begin{tabular}{|c|c|c|c|c|c|c|}
\hline \multirow[t]{2}{*}{ Variables } & \multicolumn{2}{|c|}{$\begin{array}{c}\text { Persistent male } \\
\text { breadwinner }\end{array}$} & \multicolumn{2}{|c|}{$\begin{array}{l}\text { Temporary female } \\
\text { breadwinner }\end{array}$} & \multicolumn{2}{|c|}{$\begin{array}{c}\text { Persistent female } \\
\text { breadwinner }\end{array}$} \\
\hline & Men & Women & Men & Women & Men & Women \\
\hline Age (years) & 41.6 & 39.4 & 38.7 & 36.4 & $\begin{array}{c}46.4 \\
(.000)\end{array}$ & $\begin{array}{c}43.2 \\
(.000)\end{array}$ \\
\hline English as a second language & $10.1 \%$ & $12.3 \%$ & $12.1 \%$ & $11.7 \%$ & $\begin{array}{l}15.9 \% \\
(.349)\end{array}$ & $\begin{array}{l}14.9 \% \\
(.404)\end{array}$ \\
\hline $\begin{array}{l}\text { Aboriginal or Torres Straight } \\
\text { Islander }\end{array}$ & $1.3 \%$ & $1.4 \%$ & $2.2 \%$ & $2.7 \%$ & $\begin{array}{l}0.7 \% \\
(.235)\end{array}$ & $\begin{array}{c}0 \% \\
(.038)\end{array}$ \\
\hline $\begin{array}{l}\text { No. of years married (incl de } \\
\text { facto) }\end{array}$ & \multicolumn{2}{|c|}{14.3} & \multicolumn{2}{|c|}{11.1} & \multicolumn{2}{|c|}{$\begin{array}{l}16.6 \\
(.000)\end{array}$} \\
\hline Net household worth & \multicolumn{2}{|c|}{$\$ 459,573$} & \multicolumn{2}{|c|}{$\$ 393,755$} & \multicolumn{2}{|c|}{$\begin{array}{l}\$ 488.424 \\
\quad(.003)\end{array}$} \\
\hline Bachelor degree or higher & $27.1 \%$ & $20.0 \%$ & $26.1 \%$ & $29.3 \%$ & $\begin{array}{l}20.1 \% \\
(.181)\end{array}$ & $\begin{array}{l}34.7 \% \\
(.264)\end{array}$ \\
\hline $\begin{array}{l}\text { Professional / managerial } \\
\text { occupation }\end{array}$ & $35.9 \%$ & $15.9 \%$ & $26.2 \%$ & $35.1 \%$ & $\begin{array}{l}17.3 \% \\
(.034)\end{array}$ & $\begin{array}{l}48.6 \% \\
(.008)\end{array}$ \\
\hline Unemployed & $0 \%$ & $3.0 \%$ & $5.4 \%$ & $1.0 \%$ & $\begin{array}{l}7.5 \% \\
(.415)\end{array}$ & $\begin{array}{c}0 \% \\
(.156)\end{array}$ \\
\hline Full-time employed & $95.7 \%$ & $22.5 \%$ & $77.4 \%$ & $64.3 \%$ & $\begin{array}{l}51.4 \% \\
(.000)\end{array}$ & $\begin{array}{l}73.0 \% \\
(.066)\end{array}$ \\
\hline Part-time employed & $4.3 \%$ & $36.7 \%$ & $11.9 \%$ & $28.0 \%$ & $\begin{array}{l}18.1 \% \\
(.086)\end{array}$ & $\begin{array}{l}27.0 \% \\
(.820)\end{array}$ \\
\hline Usual weekly work hours & 45.8 & 28.2 & 44.9 & 36.8 & $\begin{array}{c}40.2 \\
(.002)\end{array}$ & $\begin{array}{c}37.1 \\
(.727)\end{array}$ \\
\hline $\begin{array}{l}\text { Parents of dependent children } \\
\text { under the age of } 15\end{array}$ & \multicolumn{2}{|c|}{$85.1 \%$} & \multicolumn{2}{|c|}{$60.9 \%$} & \multicolumn{2}{|c|}{$\begin{array}{l}74.5 \% \\
(.000)\end{array}$} \\
\hline $\begin{array}{l}\text { No. of children under } 15 \\
\text { (parent sub-sample) }\end{array}$ & \multicolumn{2}{|c|}{1.25} & \multicolumn{2}{|c|}{1.05} & \multicolumn{2}{|c|}{$\begin{array}{c}0.66 \\
(.000)\end{array}$} \\
\hline $\begin{array}{l}\text { No. of children under } 5 \text { (parent } \\
\text { sub-sample) }\end{array}$ & \multicolumn{2}{|c|}{0.45} & \multicolumn{2}{|c|}{0.28} & \multicolumn{2}{|c|}{$\begin{array}{c}0.11 \\
(.000)\end{array}$} \\
\hline $\begin{array}{l}\text { Weekly hours spent with } \\
\text { children (parent sub-sample) }\end{array}$ & 9.2 & 21.0 & 6.5 & 14.4 & $\begin{array}{l}5.8 \\
(.186)\end{array}$ & $\begin{array}{c}8.1 \\
(.007)\end{array}$ \\
\hline $\begin{array}{l}\text { Preferred usual weekly work } \\
\text { hours }\end{array}$ & 42.5 & 27.1 & 42.4 & 33.4 & $\begin{array}{l}39.7 \\
(.048)\end{array}$ & $\begin{array}{c}34.3 \\
(.383)\end{array}$ \\
\hline Weekly hours on housework & 5.2 & 21.0 & 6.5 & 14.4 & $\begin{array}{l}8.3 \\
(.019)\end{array}$ & $\begin{array}{l}15.1 \\
(.537)\end{array}$ \\
\hline Gender role ideology index & 25.4 & 26.2 & 26.0 & 27.9 & $\begin{array}{c}26.2 \\
(.620)\end{array}$ & $\begin{array}{l}27.6 \\
(.571)\end{array}$ \\
\hline No. of observations & \multicolumn{2}{|c|}{2030} & \multicolumn{2}{|c|}{400} & \multicolumn{2}{|c|}{442} \\
\hline
\end{tabular}

Notes: Figures are based upon an analysis of a balanced panel of observations from HILDA Waves 1 \& 2 using longitudinal population weights. 
Table 4 reports parallel results for the two subcategories among persistent female breadwinner families. The values in parentheses are relevant to tests of Hypothesis 2, addressing the potential divergence between the economic and equity types of persistent female breadwinner families. Regarding the first four variables for demographic characteristics, two significant differences are found: men in the equity families tend to be younger, and they are less likely to have learned English as a second language. In terms of the three SES variables, two significant differences are found. The men in the equity families are more highly educated, and the women in those families are more likely to be employed in a managerial or professional occupation. For labour market status, the women in the equity type of persistent female breadwinner families are slightly (though not quite at the five per cent level) more likely to be full-time employed and less likely to be part-time employed, and work significantly longer workweeks. For the family commitment variables, two of the nine tests are significant. These tests show mothers in the equity type of families performing significantly less child care and housework than mothers in the economic type. Not surprisingly, given that the GRI index was used to distinguish the two types of families, the differences in the mean GRI values are significant.

If we discount the GRI test, a total of seven of the 29 tests undertaken achieved significance at the five per cent level or better. Although not as strong as our results for hypothesis 1 , the odds of finding significance in these tests if no relationship in fact exists are still very small. ${ }^{9}$

With confirming evidence for both hypotheses 1 and 2 concerning the basic typology of female breadwinner families, we turn to the sub-hypotheses. Hypothesis 1a states that the characteristics of temporary female breadwinner families should fall in between those for persistent male and female breadwinner families. Returning to Table 3, and treating men and women separately where the data permit, a total of 31 comparisons are available. Starting with age, we find that both men and (separately) women in temporary female breadwinner families are younger than those in the other groups, so these initial two comparisons fail to support Hypothesis 1a. One of the English-as-a-second-language comparisons fits the hypothesis (for men), while the other does not (for women). The Aboriginal and Torres Straight Islander comparisons, the number of years married or partnered, and family net worth, also do not exhibit the predicted pattern, although both educational comparisons, and both comparisons for professional or managerial employment are consistent with the 
Table 4: Characteristics of men, women and families in persistent female breadwinner couples by male's gender equity views (p-values for hypothesis 2 in parentheses)

\begin{tabular}{|c|c|c|c|c|}
\hline \multirow[t]{2}{*}{ Variables } & \multicolumn{2}{|c|}{$\begin{array}{l}\text { Economic type (male } \\
\text { neutral or opposed to } \\
\text { gender equity) }\end{array}$} & \multicolumn{2}{|c|}{$\begin{array}{l}\text { Equity type (male supports } \\
\text { gender equity) }\end{array}$} \\
\hline & Men & Women & Men & Women \\
\hline Age (years) & 47.2 & 43.4 & $\begin{array}{c}43.7 \\
(.048)\end{array}$ & $\begin{array}{c}42.3 \\
(.476)\end{array}$ \\
\hline English as a second language & $18.6 \%$ & $16.1 \%$ & $\begin{array}{l}5.7 \% \\
(.013)\end{array}$ & $\begin{array}{l}10.0 \% \\
(.300)\end{array}$ \\
\hline Aboriginal or Torres Straight Islander & $0 \%$ & $0 \%$ & $\begin{array}{l}3.4 \% \\
(.308)\end{array}$ & $\begin{array}{c}0 \% \\
(.327)\end{array}$ \\
\hline No. of years married (incl. de facto) & \multicolumn{2}{|c|}{17.0} & \multicolumn{2}{|c|}{$\begin{array}{c}15.0 \\
(.129)\end{array}$} \\
\hline Net household worth & \multicolumn{2}{|c|}{$\$ 495,319$} & \multicolumn{2}{|c|}{$\begin{array}{l}\$ 461,998 \\
(.480)\end{array}$} \\
\hline Bachelor degree or higher & $16.5 \%$ & $34.7 \%$ & $\begin{array}{r}33.5 \% \\
(.038)\end{array}$ & $\begin{array}{l}42.6 \% \\
(.238)\end{array}$ \\
\hline Professional / managerial occupation & $16.0 \%$ & $44.8 \%$ & $\begin{array}{l}22.1 \% \\
(.389)\end{array}$ & $\begin{array}{l}63.6 \% \\
(.027)\end{array}$ \\
\hline Unemployed & $7.8 \%$ & $0 \%$ & $\begin{array}{l}6.2 \% \\
(.719)\end{array}$ & $\begin{array}{c}0 \% \\
\text { (N.A.) }\end{array}$ \\
\hline Full-time employed & $51.0 \%$ & $70.5 \%$ & $\begin{array}{l}53.1 \% \\
(.815)\end{array}$ & $\begin{array}{l}83.0 \% \\
(.051)\end{array}$ \\
\hline Part-time employed & $16.9 \%$ & $29.6 \%$ & $\begin{array}{l}22.5 \% \\
(.426)\end{array}$ & $\begin{array}{l}17.0 \% \\
(.051)\end{array}$ \\
\hline Usual weekly work hours & 41.1 & 36.3 & $\begin{array}{l}36.9 \\
(.077)\end{array}$ & $\begin{array}{c}40.7 \\
(.010)\end{array}$ \\
\hline $\begin{array}{l}\text { Parents of dependent children under } \\
\text { the age of } 15\end{array}$ & \multicolumn{2}{|c|}{$75.6 \%$} & \multicolumn{2}{|c|}{$\begin{array}{l}70.1 \% \\
(.333)\end{array}$} \\
\hline $\begin{array}{l}\text { No. of children under } 15 \text { (parent sub- } \\
\text { sample) }\end{array}$ & \multicolumn{2}{|c|}{0.61} & \multicolumn{2}{|c|}{$\begin{array}{c}0.85 \\
(.096)\end{array}$} \\
\hline $\begin{array}{l}\text { No. of children under } 5 \text { (parent sub- } \\
\text { sample) }\end{array}$ & \multicolumn{2}{|c|}{0.09} & \multicolumn{2}{|c|}{$\begin{array}{c}0.19 \\
(.211)\end{array}$} \\
\hline $\begin{array}{l}\text { Weekly hours spent with children } \\
\text { (parent sub-sample) }\end{array}$ & 5.2 & 8.8 & $\begin{array}{c}8.7 \\
(.128)\end{array}$ & $\begin{array}{l}5.3 \\
(.022)\end{array}$ \\
\hline Preferred usual weekly work hours & 40.7 & 34.5 & $\begin{array}{c}36.2 \\
(.058)\end{array}$ & $\begin{array}{c}33.5 \\
(.582)\end{array}$ \\
\hline Weekly hours on housework & 7.8 & 16.0 & $\begin{array}{l}10.3 \\
(.148)\end{array}$ & $\begin{array}{l}11.6 \\
(.008)\end{array}$ \\
\hline Gender role ideology index & 24.8 & 27.0 & $\begin{array}{l}31.8 \\
(.000)\end{array}$ & $\begin{array}{l}30.0 \\
(.000)\end{array}$ \\
\hline No. of observations & \multicolumn{2}{|c|}{346} & \multicolumn{2}{|c|}{96} \\
\hline
\end{tabular}

Notes: Figures are based upon an analysis of a balanced panel of observations from HILDA Survey Waves 1 and 2 using longitudinal population weights. 
prediction. For the labour market variables, with four variables and eight comparisons, every comparison fits the prediction. Regarding the six family commitment variables and nine available comparisons, a full six of the comparisons exhibit the expected pattern with temporary female breadwinner characteristics found in between those for persistent male and female breadwinner families. Finally, one of the two GRI comparisons (that for men) fits the prediction. In sum, 20 of the 31 comparisons are consistent with the predictions of Hypothesis 1a. We thus take these findings as being generally supportive of Hypothesis 1a. Our interpretation of this hypothesis - that persistent female breadwinner families epitomise the phenomenon of female breadwinning - is therefore also supported.

In contrast, the pattern of results reported in Table 3 provides no support for Hypothesis 1b. Unemployment rates are not significantly higher for temporary female breadwinner families relative to the two other major family types analysed here. Male unemployment is highest in persistent female breadwinner families, while female unemployment is highest in persistent male breadwinner families.

Our hypothesis that temporary female breadwinning might often be linked to economic security strategies - with one member of the couple receiving more stable earnings as insurance against earnings fluctuations for the other - is not supported. However, it is worth examining the data to see if other patterns exist. Considering variables where the temporary female breadwinner families are most extreme (regardless of statistical significance), we find that as a group they are younger, more likely to be Aboriginal or Torres Straight Islanders, married or partnered for the fewest years, holding the lowest net worth, the least likely to be parents and, for the women, exhibiting the highest GRI values. Temporary female breadwinning thus tends to be concentrated among young, childless couples. It also seems likely that many of these couples will leave this state as they age.

Hypothesis 2a asserts that men in economic as opposed to the equity type of persistent female breadwinner families will exhibit lower SES, a weaker position in the labour market, and a lesser commitment to family. Relevant figures can be found in Table 4. Excluding variables measured at the level of the family, the SES figures for men's educational attainment and employment in managerial and professional occupations both fit the prediction, as do the patterns for unemployment and for full-time employment. For the family commitment variables, the patterns of weekly hours spent with children, preferred usual weekly work hours, and average hours on housework among men are all also consistent with the hypothesis. In other words, each of the figures reported here fits hypothesis 2a. In 
comparison to the men involved in the equity type of persistent female breadwinner families, these men are, as we hypothesised, accepting of female breadwinning mainly for economic reasons - either due to their own failures in the labour market or due to their wives' career successes - and they are not particularly committed to their families. Indeed, comparing across Table 3 and 4, we find that the mean GRI index value is slightly lower for men in the economic type of persistent female breadwinner family relative to the men in persistent male breadwinner families.

The final hypothesis, 2b, concerns the possibility that the women in equity as opposed to economic persistent female breadwinner families will exhibit higher SES, and rear a larger number of children while simultaneously performing less housework and child care. Returning to Table 4, we find the women in the equity type of family indeed exhibiting higher levels of education and more frequent employment in professional and managerial occupations. They are more often childless yet, among the parents, tend to have a larger number of children. Also among parents, even though these women are raising a larger number of children, they spend less time on child care. Regardless of parenthood, women in the equity group spend significantly less time on housework, as hypothesised. Hypothesis 2b is therefore generally supported in the data.

Replication of results reported in Tables 3 and 4, first using the five per cent earnings difference cut-off with current earnings, and then using the 10 per cent cut-off with financial year earnings data, are provided in Appendix Tables 3 through 6. For the five per cent current earnings cut-off for category definition, replication of the analyses reported in Table 3 leaves the general pattern of results and significance levels relevant to hypothesis testing virtually unchanged (see Appendix Table 3). Using the 10 per cent cut-off with financial year data and repeating the analyses reported in Table 3 results in identical patterns of relevance to Hypothesis 1 in all but one comparison - the GRI is higher for women in persistent relative to temporary female breadwinner families with the financial year data - though a few changes in significance levels appeared (see Appendix Table 4). ${ }^{10}$ Replication of the analyses reported in Table 4 after using the five per cent current earnings cut-off leaves both the general pattern of results and significance levels for testing of Hypothesis 2 unchanged (see Appendix Table 5). Repeating this exercise with the financial year data again yields a virtually identical pattern of results, though these are slightly more pronounced in terms of significance levels (see Appendix Table 6). ${ }^{11}$ We therefore take the general pattern of results reported above as reasonably robust to alternative specifications. 


\section{Discussion}

Previous research on female breadwinner families has not sought to disentangle the different reasons for and meanings of such families. We here developed and confirmed the statistical significance of distinguishing between two basic types of female breadwinner families: those where the intra-household earnings pattern is only temporary, and those where it persists over time. Further, among the latter, we found that we could distinguish between those families where the existence of female breadwinning reflected economic considerations and those where it reflected an ideological commitment to gender equity.

A key implication of the analysis is that cross-sectional estimates of female breadwinning will both over- and under-state the prevalence of female breadwinning. When we focused on a single year, couples where the woman was earning at least 10 per cent more than the man were found to represent just over 20 per cent of all Australian couples of working age. A larger proportion - 26.7 per cent - of the couples, however, exhibited female breadwinning in at least one of two years. This higher figure, which would only rise if more years of data were available, highlights the dependence of many families on the earnings of women. Nevertheless, only 13.9 per cent of the sample exhibited female breadwinning in both years. We found that for the remaining 12.8 per cent of couples where female breadwinning was temporary, their characteristics were mainly intermediate between those of persistent female and persistent male breadwinner families, consistent with the notion that they do not epitomise the phenomenon of female breadwinning. The inclusion of the temporary group in studies of female breadwinning will therefore tend to introduce substantial statistical noise into the results.

Among the persistent female breadwinner families, we found that the large majority (over 70 per cent) were in this situation for reasons we believe are fundamentally economic, rather than due to any commitment to equity. These findings are thus consistent with the notion that persistent female breadwinner families arise mainly due to failures of men in the labour market or due to the successes of their wives and partners. The men in this group exhibited the highest rates of unemployment for any group in the sample, were only half as likely as their wives to hold a bachelor's degree, and were less than half as likely to be employed in a professional or managerial occupation. These men are not committed to any sort of gender role reversal and, relative to men in the equity group, perform less child care and less housework. These men may well wish for a return to the traditional male breadwinner family 
structure. However, given the economic basis for this group, it is not clear that the labour market will allow these men to return to traditional roles.

The equity oriented persistent female breadwinner families represent, as we supposed, not so much a reversal of traditional gender roles as a family form that offers economic and family success in tandem with gender equity. This group provides cause for hope for a feminist vision of families that can simultaneously achieve all three objectives. Yet the small size of this group, representing less than three per cent of all couples, suggests that much work remains if this vision is to become a reality for a majority of families.

Finally, one might reasonably ask where the "Mr Mom” families appear in our analysis. We define these families as having a persistent female breadwinner, with a father who is not committed to gender equity, and with the man performing a majority of child care. The relevant sub-sample of the economic type of persistent female breadwinner family then comprises a total of 66 individuals, and a weighted 1.99 per cent of all individuals in our overall sample. This group is far smaller than the 96 individuals found in the equity type of persistent female breadwinner families, and represents less than one-fifth of the economic persistent female breadwinner families. We, therefore, believe it reasonable to conclude that true gender role reversal is relatively rare. Instead, among the persistent female breadwinner families, where role reversals were most likely to be identified, the men in the economic type did not typically take on the levels of housework and child care that role reversal would suggest, while men in the equity type appeared more committed to creating equality than to taking over traditional female roles in the family. 


\section{References}

Australian Bureau of Statistics [ABS] (1984) Australian Families, 1982 (ABS cat. no. 4408.0). Canberra: Australian Bureau of Statistics.

Barnett, R. and C. Rivers (2004) Same Difference: How Gender Myths Are Hurting Our Relationships, Our Children, and Our Jobs. New York: Basic Books.

Baxter, J., B. Hewitt and M. Western (forthcoming) 'Post-Familial Families and the Domestic Division of Labor: A View from Australia', Journal of Comparative Family Studies.

Becker, G.S. (1981) A Treatise on the Family. Cambridge MA: Harvard University Press.

Brennan, R.T., R.C. Barnett and K.C. Gareis (2001) 'When She Earns More Than He Does: A Longitudinal Study of Dual-Earner Couples', Journal of Marriage and the Family 63(1): 168-182.

Bureau of Labor (2004) Women in the Labor Force: A Databook (Report 973). Washington DC: Bureau of Labor Statistics, US Department of Labor.

Deutsch, F.M. (1999) Halving It All: How Equally Shared Parenting Works. Cambridge MA: Harvard University Press.

Gerson, K. (1993) No Man's Land: Men’s Changing Commitments to Family and Work. New York NY: Basic Books.

Hakim, C. (2001) Work-Lifestyle Choices in the $21^{\text {st }}$ Century: Preference Theory. London: Oxford University Press.

Halliday, C. (2004) 'At Home with Dad’, Sun-Herald, Sunday, 11 July.

Headey, B., G. Marks and M. Wooden (2004) 'The Structure and Distribution of Household Wealth in Australia', Melbourne Institute Working Paper Series no. 12/04. Melbourne: Melbourne Institute of Applied Economic and Social Research, University of Melbourne.

Heckert, D.A., Nowak, T.C. and K.A. Snyder (1998) 'The Impact of Husbands' and Wives' Relative Earnings on Marital Disruption', Journal of Marriage and the Family 60(3): 690-703.

Hood, J.C. (1986) 'The Provider Role: Its Meaning and Measurement', Journal of Marriage and the Family 48(2): 349-359. 
Martin, G. and Kats, V. (2003) 'Families and Work in Transition in 12 Countries, 19802001’, Monthly Labor Review 127(9): 3-31.

Oppenheimer, V.K. (1997) 'Women's Employment and the Gain to Marriage: The Specialization and Trading Model’, Annual Review of Sociology 23: 431-453.

Parsons, T. (1949) 'The Social Structure of the Family', pp. 173-201 in R. Anshen (ed.) The Family: Its Function and Destiny. New York: Harper.

Risman, B.J. (1998) Gender Vertigo: American Families in Transition. New Haven CN: Yale University Press.

Rogers, S.J. and D.D. DeBoer (2001) 'Changes in Wives' Income: Effects on Marital Happiness, Psychological Well-being, and the Risk of Divorce', Journal of Marriage and the Family 63(2): 458-471.

Watson, N. and M. Wooden (2002) 'The Household, Income and Labour Dynamics in Australia (HILDA) Survey: Wave One Survey Methodology’, HILDA Project Technical Paper Series no. 1/02. Melbourne: Melbourne Institute of Applied Economic and Social Research, University of Melbourne.

Weston, R., D. Stanton, L. Qu and G. Soriano (2001) 'Australian Families in Transition: Socio-demographic Trends 1901-2001’, Family Matters, no. 60: 12-23.

Williams, J. (1999) Unbending Gender. London: Oxford University Press. 


\section{Endnotes}

${ }^{1}$ Australian figures derived from data available in electronic form on the Australian Bureau of Statistics website (Labour Force, Australia, Detailed - Electronic Delivery, Annual - ABS cat. no. 6291.0.55.001).

${ }^{2}$ This figure is derived from ABS, Education and Work, May 2003 (ABS cat. no. 6227.0).

${ }^{3}$ This claim may not, however, hold in the case of poor families, where the income of both members of the couple will likely be crucial to economic survival.

${ }^{4}$ More specifically, the data used are from the HILDA Survey confidentialised unit-record file, Wave 1-Wave 2, release 2.0, issued on CD-Rom in January 2004.

${ }^{5}$ Note the latter family form includes four categories: female breadwinner in W1 and either about equal or male breadwinner in W2, and female breadwinner in W2 with either about equal or male breadwinner in W1.

${ }^{6}$ Excluded categories cover: male breadwinner in W1 and about equal in W2, about equal in W1 and male breadwinner in W2, and about equal in W1 and in W2. See Table 1 below for category sizes.

${ }^{7}$ Note that because the "intermediate" claim in hypothesis 1a represents our interpretation for why temporary and persistent female breadwinner families should be split, there is no obvious reason to test for statistical divergence between persistent male breadwinner and temporary female breadwinner families.

${ }^{8}$ Specifically, if the variables are randomly and independently distributed, the odds of achieving significance at the five per cent level in at least one of two independent tests is .05 (.95 x .05 plus $.05 \times .05)$. The probability of achieving the same result in four tests is .0025 $(.05 \times$.05). For eight tests the figure is $.00000625(.0025 \times$.0025) and, following the logic out, the odds of achieving significance in least half of 32 tests is $.120 \times 10^{-18}$.

${ }^{9}$ One quarter of the tests achieved significance. Again assuming the variables are randomly and independently distributed, the odds of having no test achieve significance out of four independent tests is $.81451\left(.95^{4}\right)$; conversely, the odds of at least one test achieve significance is .18549. Extending the exercise shows that the odds of at least 8 tests out of 32 achieving significance when no relationship in fact exists are .000001401 , or around 1 in over 700,000 . 
${ }^{10}$ Considering cases where significance rises or falls from above $10 \%$ to below $5 \%$, or from above $5 \%$ to below $1 \%$, we find the Net household worth test losing significance, the number of children under 15 test losing significance, and the GRI test result rising to significance when the financial year data is employed.

${ }^{11}$ Using the same criteria as above, patterns remain as before but significance levels improve for the women with English as a second language, Number of years married, and parents of dependent children tests using the financial year data, while significance is lost for the test on usual weekly work hours for women. 
Appendix Table 1: Percentage (numeric) distribution of couple families over time, using usual earnings data and $5 \%$ cut-off

\begin{tabular}{lccc}
\hline & Male & About equal & $\begin{array}{c}\text { Female } \\
\text { breadwinner W2 }\end{array}$ \\
\cline { 2 - 4 } Male breadwinner W1 & $63.9 \%$ & $2.6 \%$ & $4.9 \%$ \\
& $(2084)$ & $(82)$ & $(158)$ \\
About equal W1 & $2.7 \%$ & $1.8 \%$ & $1.6 \%$ \\
& $(78)$ & $(62)$ & $(42)$ \\
Female breadwinner W1 & $5.5 \%$ & $2.2 \%$ & $14.7 \%$ \\
& $(174)$ & $(60)$ & $(464)$ \\
\hline
\end{tabular}

Notes: Figures based upon a balanced panel of observations from HILDA W1 and W2. Numeric figures in parentheses are directly from the sample (unweighted) while sample proportions are estimated using longitudinal population weights.

Appendix Table 2: Percentage (Numeric) Distribution of Couple Families Over Time, using Financial Year Earnings data and 10\% Cut-Off

\begin{tabular}{lccc}
\hline & $\begin{array}{c}\text { Male } \\
\text { breadwinner W2 }\end{array}$ & $\begin{array}{c}\text { About equal } \\
\text { W2 }\end{array}$ & $\begin{array}{c}\text { Female } \\
\text { breadwinner W2 }\end{array}$ \\
\cline { 2 - 4 } Male breadwinner W1 & $63.4 \%$ & $3.5 \%$ & $4.1 \%$ \\
About equal W1 & $(2314)$ & $(120)$ & $(140)$ \\
& $2.3 \%$ & $3.5 \%$ & $2.4 \%$ \\
Female breadwinner W1 & $(90)$ & $(118)$ & $(74)$ \\
& $3.9 \%$ & $2.8 \%$ & $14.2 \%$ \\
& $(140)$ & $(88)$ & $(502)$ \\
\hline
\end{tabular}

Notes: Figures based upon a balanced panel of observations from HILDA W1 and W2. Numeric figures in parentheses are directly from the sample (unweighted) while sample proportions are estimated using longitudinal population weights. 
Appendix Table 3: Characteristics of men, women, and of families across persistent male, temporary female, and persistent female breadwinner families, using usual earnings data and $5 \%$ cut-off ( $p$-values for hypothesis 1 in parentheses)

\begin{tabular}{|c|c|c|c|c|c|c|}
\hline \multirow[t]{2}{*}{ Variables } & \multicolumn{2}{|c|}{$\begin{array}{l}\text { Persistent male } \\
\text { breadwinner }\end{array}$} & \multicolumn{2}{|c|}{$\begin{array}{l}\text { Temporary } \\
\text { female } \\
\text { breadwinner }\end{array}$} & \multicolumn{2}{|c|}{$\begin{array}{l}\text { Persistent female } \\
\text { breadwinner }\end{array}$} \\
\hline & Men & Women & Men & Women & Men & Women \\
\hline Age (years) & 41.5 & 39.3 & 38.5 & 36.0 & $\begin{array}{c}46.3 \\
(.000)\end{array}$ & $\begin{array}{c}43.2 \\
(.000)\end{array}$ \\
\hline English as a second language & $10.6 \%$ & $12.5 \%$ & $13.5 \%$ & $13.0 \%$ & $\begin{array}{l}15.1 \% \\
(.701)\end{array}$ & $\begin{array}{l}14.1 \% \\
(.749)\end{array}$ \\
\hline $\begin{array}{l}\text { Aboriginal or Torres Straight } \\
\text { Islander }\end{array}$ & $1.2 \%$ & $1.5 \%$ & $2.0 \%$ & $2.4 \%$ & $\begin{array}{l}.7 \% \\
(.253)\end{array}$ & $\begin{array}{c}0 \% \\
(.038)\end{array}$ \\
\hline $\begin{array}{l}\text { No. of years married (incl. de } \\
\text { facto) }\end{array}$ & \multicolumn{2}{|c|}{14.2} & \multicolumn{2}{|c|}{10.7} & \multicolumn{2}{|c|}{$\begin{array}{c}16.4 \\
(.000)\end{array}$} \\
\hline Net household worth & \multicolumn{2}{|c|}{457,840} & \multicolumn{2}{|c|}{373,471} & \multicolumn{2}{|c|}{$\begin{array}{c}498,530 \\
(.000)\end{array}$} \\
\hline Bachelor degree or higher & $27.2 \%$ & $20.3 \%$ & $25.4 \%$ & $29.1 \%$ & $\begin{array}{l}22.2 \% \\
(.473)\end{array}$ & $\begin{array}{l}36.6 \% \\
(.116)\end{array}$ \\
\hline $\begin{array}{l}\text { Professional / managerial } \\
\text { occupation }\end{array}$ & $35.6 \%$ & $16.7 \%$ & $24.2 \%$ & $34.4 \%$ & $\begin{array}{l}19.6 \% \\
(.257)\end{array}$ & $\begin{array}{l}49.2 \% \\
(.003)\end{array}$ \\
\hline Unemployed & $0 \%$ & $3.0 \%$ & $4.9 \%$ & $.9 \%$ & $\begin{array}{l}7.1 \% \\
(.356)\end{array}$ & $\begin{array}{c}0 \% \\
(.156)\end{array}$ \\
\hline Full-time employed & $95.8 \%$ & $24.1 \%$ & $80.0 \%$ & $66.8 \%$ & $\begin{array}{l}53.2 \% \\
(.000)\end{array}$ & $\begin{array}{l}74.0 \% \\
(.106)\end{array}$ \\
\hline Part-time employed & $4.2 \%$ & $36.3 \%$ & $10.3 \%$ & $25.7 \%$ & $\begin{array}{l}17.9 \% \\
(.024)\end{array}$ & $\begin{array}{l}26.0 \% \\
(.941)\end{array}$ \\
\hline Usual weekly work hours & 45.8 & 28.7 & 44.5 & 37.5 & $\begin{array}{c}40.5 \\
(.004)\end{array}$ & $\begin{array}{c}37.5 \\
(.982)\end{array}$ \\
\hline $\begin{array}{l}\text { Parents of dependent children } \\
\text { under the age of } 15\end{array}$ & \multicolumn{2}{|c|}{$84.2 \%$} & \multicolumn{2}{|c|}{$58.6 \%$} & \multicolumn{2}{|c|}{$\begin{array}{l}74.0 \% \\
(.000)\end{array}$} \\
\hline $\begin{array}{l}\text { No. of children under } 15 \text { (parent } \\
\text { sub-sample) }\end{array}$ & \multicolumn{2}{|c|}{1.23} & \multicolumn{2}{|c|}{0.99} & \multicolumn{2}{|c|}{$\begin{array}{c}0.66 \\
(.000)\end{array}$} \\
\hline $\begin{array}{l}\text { No. of children under } 5 \text { (parent } \\
\text { sub-sample) }\end{array}$ & \multicolumn{2}{|c|}{0.45} & \multicolumn{2}{|c|}{0.26} & \multicolumn{2}{|c|}{$\begin{array}{c}0.11 \\
(.000)\end{array}$} \\
\hline $\begin{array}{l}\text { Weekly hours spent with children } \\
\text { (parent sub-sample) }\end{array}$ & 9.2 & 20.9 & 7.4 & 12.5 & $\begin{array}{l}5.8 \\
(.234)\end{array}$ & $\begin{array}{c}8.4 \\
(.021)\end{array}$ \\
\hline $\begin{array}{l}\text { Preferred usual weekly work } \\
\text { hours }\end{array}$ & 42.4 & 27.4 & 42.3 & 33.7 & $\begin{array}{c}39.5 \\
(.030)\end{array}$ & $\begin{array}{c}34.6 \\
(.397)\end{array}$ \\
\hline Weekly hours on housework & 5.3 & 20.8 & 6.5 & 14.0 & $\begin{array}{l}8.3 \\
(.020)\end{array}$ & $\begin{array}{l}15.0 \\
(.376)\end{array}$ \\
\hline Gender role ideology index & 25.4 & 26.2 & 26.1 & 27.9 & $\begin{array}{c}26.2 \\
(.891)\end{array}$ & $\begin{array}{c}27.7 \\
(.614)\end{array}$ \\
\hline No. of observations & \multicolumn{2}{|c|}{2084} & \multicolumn{2}{|c|}{434} & \multicolumn{2}{|c|}{464} \\
\hline
\end{tabular}

Note: Figures from balanced panel of HILDA W1 and W2 using longitudinal population weights. 
Appendix Table 4: Characteristics of men, women, and of families across persistent male, temporary female, and persistent female breadwinner families, using financial year earnings data and 10\% cut-off (p-values for hypothesis 1 in parentheses)

\begin{tabular}{|c|c|c|c|c|c|c|}
\hline \multirow[t]{2}{*}{ Variables } & \multicolumn{2}{|c|}{$\begin{array}{l}\text { Persistent male } \\
\text { breadwinner }\end{array}$} & \multicolumn{2}{|c|}{$\begin{array}{l}\text { Temporary } \\
\text { female } \\
\text { breadwinner }\end{array}$} & \multicolumn{2}{|c|}{$\begin{array}{c}\text { Persistent female } \\
\text { breadwinner }\end{array}$} \\
\hline & Men & Women & Men & Women & Men & Women \\
\hline Age (years) & 41.4 & 39.1 & 40.7 & 38.2 & $\begin{array}{c}44.7 \\
(.000)\end{array}$ & $\begin{array}{c}41.8 \\
(.002)\end{array}$ \\
\hline English as a second language & $10.0 \%$ & $12.1 \%$ & $14.0 \%$ & $12.2 \%$ & $\begin{array}{l}14.5 \% \\
(.862)\end{array}$ & $\begin{array}{l}13.1 \% \\
(.801)\end{array}$ \\
\hline $\begin{array}{l}\text { Aboriginal or Torres Straight } \\
\text { Islander }\end{array}$ & $1.2 \%$ & $1.8 \%$ & $1.7 \%$ & $2.7 \%$ & $\begin{array}{c}0.6 \% \\
(.338)\end{array}$ & $\begin{array}{c}0 \% \\
(.032)\end{array}$ \\
\hline $\begin{array}{l}\text { No. of years married (incl. de } \\
\text { facto) }\end{array}$ & \multicolumn{2}{|c|}{14.1} & \multicolumn{2}{|c|}{12.5} & \multicolumn{2}{|c|}{$\begin{array}{c}15.4 \\
(.000)\end{array}$} \\
\hline Net household worth & \multicolumn{2}{|c|}{432,959} & \multicolumn{2}{|c|}{463,560} & \multicolumn{2}{|c|}{$\begin{array}{c}471,607 \\
(.824)\end{array}$} \\
\hline Bachelor degree or higher & $28.3 \%$ & $20.6 \%$ & $24.4 \%$ & $30.2 \%$ & $\begin{array}{l}22.0 \% \\
(.565)\end{array}$ & $\begin{array}{l}32.9 \% \\
(.559)\end{array}$ \\
\hline $\begin{array}{l}\text { Professional / managerial } \\
\text { occupation }\end{array}$ & $36.3 \%$ & $16.9 \%$ & $29.8 \%$ & $29.0 \%$ & $\begin{array}{l}21.2 \% \\
(.046)\end{array}$ & $\begin{array}{l}49.8 \% \\
(.000)\end{array}$ \\
\hline Unemployed & $0.3 \%$ & $3.2 \%$ & $2.7 \%$ & $2.0 \%$ & $\begin{array}{l}5.7 \% \\
(.141)\end{array}$ & $\begin{array}{l}0.4 \% \\
(.131)\end{array}$ \\
\hline Full-time employed & $95.0 \%$ & $24.5 \%$ & $78.8 \%$ & $58.9 \%$ & $\begin{array}{l}60.0 \% \\
(.000)\end{array}$ & $\begin{array}{l}76.7 \% \\
(.000)\end{array}$ \\
\hline Part-time employed & $4.7 \%$ & $36.1 \%$ & $11.3 \%$ & $30.6 \%$ & $\begin{array}{l}14.7 \% \\
(.285)\end{array}$ & $\begin{array}{l}22.5 \% \\
(.053)\end{array}$ \\
\hline Usual weekly work hours & 45.7 & 28.4 & 44.7 & 36.6 & $\begin{array}{c}42.4 \\
(.098)\end{array}$ & $\begin{array}{c}38.4 \\
(.150)\end{array}$ \\
\hline $\begin{array}{l}\text { Parents of dependent children } \\
\text { under the age of } 15\end{array}$ & \multicolumn{2}{|c|}{$84.2 \%$} & \multicolumn{2}{|c|}{$64.5 \%$} & \multicolumn{2}{|c|}{$\begin{array}{l}71.5 \% \\
(.032)\end{array}$} \\
\hline $\begin{array}{l}\text { No. of children under } 15 \text { (parent } \\
\text { sub-sample) }\end{array}$ & \multicolumn{2}{|c|}{1.28} & \multicolumn{2}{|c|}{0.81} & \multicolumn{2}{|c|}{$\begin{array}{c}0.71 \\
(.246)\end{array}$} \\
\hline $\begin{array}{l}\text { No. of children under } 5 \text { (parent } \\
\text { sub-sample) }\end{array}$ & \multicolumn{2}{|c|}{0.47} & \multicolumn{2}{|c|}{0.24} & \multicolumn{2}{|c|}{$\begin{array}{c}0.16 \\
(.042)\end{array}$} \\
\hline $\begin{array}{l}\text { Weekly hours spent with children } \\
\text { (parent sub-sample) }\end{array}$ & 9.4 & 20.6 & 7.3 & 13.9 & $\begin{array}{l}7.0 \\
(.807)\end{array}$ & $\begin{array}{c}8.7 \\
(.006)\end{array}$ \\
\hline $\begin{array}{l}\text { Preferred usual weekly work } \\
\text { hours }\end{array}$ & 42.4 & 26.9 & 41.7 & 33.3 & $\begin{array}{c}40.4 \\
(.295)\end{array}$ & $\begin{array}{c}34.8 \\
(.152)\end{array}$ \\
\hline Weekly hours on housework & 5.3 & 20.7 & 5.8 & 15.8 & $\begin{array}{l}8.7 \\
(.000)\end{array}$ & $\begin{array}{c}14.1 \\
(.136)\end{array}$ \\
\hline Gender role ideology index & 25.4 & 26.2 & 25.6 & 27.3 & $\begin{array}{c}26.6 \\
(.029)\end{array}$ & $\begin{array}{c}28.2 \\
(.036)\end{array}$ \\
\hline No. of observations & \multicolumn{2}{|c|}{2314} & \multicolumn{2}{|c|}{442} & \multicolumn{2}{|c|}{502} \\
\hline
\end{tabular}

Note: Figures from balanced panel of HILDA W1 and W2 using longitudinal population weights. 
Appendix Table 5: Characteristics of men, women and families in persistent female breadwinner couples by male's gender equity views, using usual earnings data and 5\% cut-off (p-values for hypothesis 2 in parentheses)

\begin{tabular}{|c|c|c|c|c|}
\hline \multirow[t]{2}{*}{ Variables } & \multicolumn{2}{|c|}{$\begin{array}{c}\text { Economic type (male } \\
\text { neutral or opposed to } \\
\text { gender equity) }\end{array}$} & \multicolumn{2}{|c|}{$\begin{array}{c}\text { Equity type (male } \\
\text { supports gender equity) }\end{array}$} \\
\hline & Men & Women & Men & Women \\
\hline Age (years) & 47.0 & 43.5 & $\begin{array}{l}43.7 \\
(.054)\end{array}$ & $\begin{array}{l}42.1 \\
(.397)\end{array}$ \\
\hline English as a second language & $17.7 \%$ & $15.3 \%$ & $\begin{array}{l}5.4 \% \\
(.013)\end{array}$ & $\begin{array}{l}9.4 \% \\
(.291)\end{array}$ \\
\hline Aboriginal or Torres Straight Islander & $0 \%$ & $0 \%$ & $\begin{array}{l}3.2 \% \\
(.308)\end{array}$ & $\begin{array}{c}0 \% \\
(.328)\end{array}$ \\
\hline No. of years married (incl. de facto) & \multicolumn{2}{|c|}{16.8} & \multicolumn{2}{|c|}{$\begin{array}{c}15.0 \\
(.147)\end{array}$} \\
\hline Net household worth & \multicolumn{2}{|c|}{509,534} & \multicolumn{2}{|c|}{$\begin{array}{l}456,582 \\
(.248)\end{array}$} \\
\hline Bachelor degree or higher & $18.7 \%$ & $34.2 \%$ & $\begin{array}{l}35.4 \% \\
(.038)\end{array}$ & $\begin{array}{l}45.8 \% \\
(.162)\end{array}$ \\
\hline Professional / managerial occupation & $17.8 \%$ & $45.5 \%$ & $\begin{array}{l}26.2 \% \\
(.245)\end{array}$ & $\begin{array}{l}63.7 \% \\
(.027)\end{array}$ \\
\hline Unemployed & $7.4 \%$ & $0 \%$ & $\begin{array}{l}5.9 \% \\
(.717)\end{array}$ & $\begin{array}{c}0 \% \\
\text { (N.A) }\end{array}$ \\
\hline Full-time employed & $52.6 \%$ & $71.5 \%$ & $\begin{array}{l}55.6 \% \\
(.729)\end{array}$ & $\begin{array}{l}84.0 \% \\
(.042)\end{array}$ \\
\hline Part-time employed & $16.9 \%$ & $28.5 \%$ & $\begin{array}{l}21.3 \% \\
(.517)\end{array}$ & $\begin{array}{l}16.0 \% \\
(.042)\end{array}$ \\
\hline Usual weekly work hours & 41.4 & 36.6 & $\begin{array}{l}37.6 \\
(.099)\end{array}$ & $\begin{array}{c}41.1 \\
(.006)\end{array}$ \\
\hline $\begin{array}{l}\text { Parents of dependent children under } \\
\text { the age of } 15\end{array}$ & \multicolumn{2}{|c|}{$75.1 \%$} & \multicolumn{2}{|c|}{$\begin{array}{l}69.8 \% \\
(.340)\end{array}$} \\
\hline $\begin{array}{l}\text { No. of children under } 15 \text { (parent sub- } \\
\text { sample) }\end{array}$ & \multicolumn{2}{|c|}{0.62} & \multicolumn{2}{|c|}{$\begin{array}{c}0.84 \\
(.106)\end{array}$} \\
\hline $\begin{array}{l}\text { No. of children under } 5 \text { (parent sub- } \\
\text { sample) }\end{array}$ & \multicolumn{2}{|c|}{0.09} & \multicolumn{2}{|c|}{$\begin{array}{c}0.18 \\
(.236)\end{array}$} \\
\hline $\begin{array}{l}\text { Weekly hours spent with children } \\
\text { (parent sub-sample) }\end{array}$ & 5.2 & 9.2 & $\begin{array}{l}8.6 \\
(.121)\end{array}$ & $\begin{array}{c}5.4 \\
(.014)\end{array}$ \\
\hline Preferred usual weekly work hours & 40.5 & 34.6 & $\begin{array}{l}36.2 \\
(.059)\end{array}$ & $\begin{array}{c}34.3 \\
(.845)\end{array}$ \\
\hline Weekly hours on housework & 7.8 & 15.9 & $\begin{array}{l}10.1 \\
(.169)\end{array}$ & $\begin{array}{l}11.6 \\
(.007)\end{array}$ \\
\hline Gender role ideology index & 24.7 & 27.1 & $\begin{array}{l}31.7 \\
(.000)\end{array}$ & $\begin{array}{c}30.1 \\
(.000)\end{array}$ \\
\hline No. of observations & \multicolumn{2}{|c|}{36} & \multicolumn{2}{|c|}{102} \\
\hline
\end{tabular}

Note: Figures from balanced panel of HILDA W1 and W2 using longitudinal population weights. 
Appendix Table 6: Characteristics of men, women and families in persistent female breadwinner couples by male's gender equity views, using financial year earnings data and $10 \%$ cut-off ( $\mathrm{p}$-values for hypothesis 2 in parentheses)

\begin{tabular}{|c|c|c|c|c|}
\hline \multirow[t]{2}{*}{ Variables } & \multicolumn{2}{|c|}{$\begin{array}{l}\text { Economic type (male } \\
\text { neutral or opposed to } \\
\text { gender equity) }\end{array}$} & \multicolumn{2}{|c|}{$\begin{array}{c}\text { Equity type (male } \\
\text { supports gender equity) }\end{array}$} \\
\hline & Men & Women & Men & Women \\
\hline Age (years) & 46.1 & 42.6 & $\begin{array}{c}40.9 \\
(.001)\end{array}$ & $\begin{array}{c}39.4 \\
(.060)\end{array}$ \\
\hline English as a second language & $18.4 \%$ & $15.2 \%$ & $\begin{array}{l}4.1 \% \\
(.001)\end{array}$ & $\begin{array}{l}7.0 \% \\
(.079)\end{array}$ \\
\hline Aboriginal or Torres Straight Islander & $0 \%$ & $0 \%$ & $\begin{array}{l}2.4 \% \\
(.311)\end{array}$ & $\begin{array}{c}0 \% \\
\text { (N.A) }\end{array}$ \\
\hline No. of years married (incl. de facto) & \multicolumn{2}{|c|}{16.2} & \multicolumn{2}{|c|}{$\begin{array}{c}13.1 \\
(.009)\end{array}$} \\
\hline Net household worth & \multicolumn{2}{|c|}{486,257} & \multicolumn{2}{|c|}{$\begin{array}{l}429,712 \\
(.259)\end{array}$} \\
\hline Bachelor degree or higher & $16.1 \%$ & $29.5 \%$ & $\begin{array}{l}38.4 \% \\
(.002)\end{array}$ & $\begin{array}{l}42.8 \% \\
(.066)\end{array}$ \\
\hline Professional / managerial occupation & $19.3 \%$ & $43.6 \%$ & $\begin{array}{l}26.7 \% \\
(.245)\end{array}$ & $\begin{array}{l}68.1 \% \\
(.001)\end{array}$ \\
\hline Unemployed & $6.0 \%$ & $0.6 \%$ & $\begin{array}{l}4.7 \% \\
(.706)\end{array}$ & $\begin{array}{l}0 \% \\
(.317)\end{array}$ \\
\hline Full-time employed & $59.1 \%$ & $75.0 \%$ & $\begin{array}{l}62.7 \% \\
(.629)\end{array}$ & $\begin{array}{l}81.7 \% \\
(.264)\end{array}$ \\
\hline Part-time employed & $13.4 \%$ & $24.4 \%$ & $\begin{array}{l}18.3 \% \\
(.383)\end{array}$ & $\begin{array}{l}17.0 \% \\
(.209)\end{array}$ \\
\hline Usual weekly work hours & 43.5 & 37.8 & $\begin{array}{l}39.6 \\
(.092)\end{array}$ & $\begin{array}{c}40.2 \\
(.122)\end{array}$ \\
\hline $\begin{array}{l}\text { Parents of dependent children under } \\
\text { the age of } 15\end{array}$ & \multicolumn{2}{|c|}{$74.6 \%$} & \multicolumn{2}{|c|}{$\begin{array}{l}62.8 \% \\
(.021)\end{array}$} \\
\hline $\begin{array}{l}\text { No. of children under } 15 \text { (parent sub- } \\
\text { sample) }\end{array}$ & \multicolumn{2}{|c|}{0.67} & \multicolumn{2}{|c|}{$\begin{array}{c}0.88 \\
(.093)\end{array}$} \\
\hline $\begin{array}{l}\text { No. of children under } 5 \text { (parent sub- } \\
\text { sample) }\end{array}$ & \multicolumn{2}{|c|}{0.14} & \multicolumn{2}{|c|}{$\begin{array}{c}0.22 \\
(.311)\end{array}$} \\
\hline $\begin{array}{l}\text { Weekly hours spent with children } \\
\text { (parent sub-sample) }\end{array}$ & 6.0 & 9.4 & $\begin{array}{l}10.2 \\
(.077)\end{array}$ & $\begin{array}{c}6.2 \\
(.038)\end{array}$ \\
\hline Preferred usual weekly work hours & 42.0 & 34.7 & $\begin{array}{l}36.3 \\
(.007)\end{array}$ & $\begin{array}{l}35.0 \\
(.827)\end{array}$ \\
\hline Weekly hours on housework & 8.1 & 14.9 & $\begin{array}{l}10.4 \\
(.091)\end{array}$ & $\begin{array}{l}11.8 \\
(.039)\end{array}$ \\
\hline Gender role ideology index & 24.6 & 27.5 & $\begin{array}{l}32.2 \\
(.000)\end{array}$ & $\begin{array}{l}30.4 \\
(.000)\end{array}$ \\
\hline No. of observations & \multicolumn{2}{|c|}{366} & \multicolumn{2}{|c|}{136} \\
\hline
\end{tabular}

Note: Figures from balanced panel of HILDA W1 \& 2 using longitudinal population weights. 